\title{
Pasienten ble vurdert psykotisk
}

\author{
Jeg har festet meg ved et fenomen som synes å bre seg blant leger. Det gjelder utelatelse av ordene \\ som og være i spesielle, viktige sammenhenger, både i interne sykehusjournaler, brev og erklæringer. \\ Noen eksempler illustrerer fenomenet.
}

Pasienten ble vurdert psykotisk/pasienten oppfattes suicidal/pasienten undersøkes og vurderes urolig og uberegnelig. For alle disse utsagnene gjelder at man i større eller mindre grad blir i villrede om hvem som gjør hva av pasient og undersøker, og hvem beskrivelsene er myntet på. Dette gjelder særlig det siste av de tre eksemplene. Ved utelatelse av som står det faktisk at pasienten undersøkes på en urolig og uberegnelig måte! For meg skurrer språkbruken. Jeg mener at den korrekte uttrykksmåten er: «Pasienten undersøkes og vurderes som urolig og uberegnelig.»

I eksemplet pasienten finnes farlig, ville jeg måtte bruke en noe lengre formulering: «Pasienten finnes å voere farlig.» Den forkortede versjonen kan sette leseren på den tanken at pasienten er blitt påtruffet på en for finneren farlig måte.

I TV-overføringen av terrorrettssaken 14.6.2012 brukte de sakkyndige formuleringene «... anses syk» og «... fremstår ikke inkoherent.»

\section{Diskusjon}

Som kan være både konjunksjon (bindeord) og ubestemt relativt pronomen (1). Det er sistnevnte funksjon jeg omtaler her.

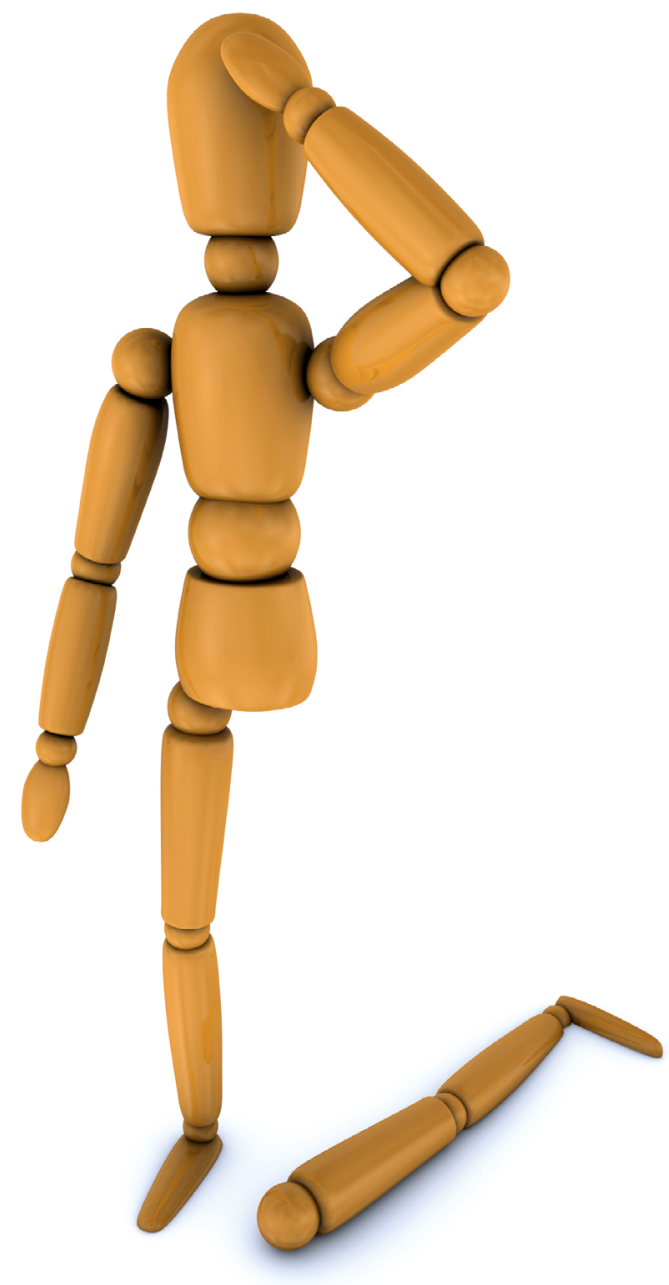

Bortfall av som i relativsetninger er omtalt i Kunnskapsforlagets Håndbok i norsk: «Vi kan utelate som når det f.eks. ville ha stått som objekt - Den hytta du ser der, er min. Men vi utelater ikke som når det ville ha stått som subjekt, når relativsetningen er unødvendig, eller når det står et like eller samme rett før korrelatet.»

I Norsk riksmålsordbok fra 1983 angis at som kan ha opptil ti forskjellige betydninger (2). Videre angis at: «... som brukes for å tilknytte et ledd (ofte en setning) for å uttrykke likhet, sidestilling, parallellitet i art eller forhold, måte og omstendigheter.» Under punkt 5a anvendes nettopp utsagnet «regne en som gal» for å illustrere den nødvendige bruken av som »... i uttrykk for klassifisering, synspunkt på grunnlag av vurdering, mening og skjønn».

Språkviteren Sylfest Lomheim deler mine synspunkter. «Og du har ikkje berre eit poeng; du har rett, det du siterer er dårleg og uklar språkføring. «SOM» må vera med, i det dømet du nemner» (S. Lomheim, personlig meddelelse).

Kanskje henger dette fenomenet sammen med den tendensen vi mennesker har til å forenkle og forkorte ord og faste uttrykk, av og til slik at det går utover presisjonen.

Denne utviklingen påskyndes antakelig også av det komprimerte mobiltelefonspråket som har utviklet seg.

Torbjørn Vatnaland

tovatna@online.no

Oslo

Torbjørn Vatnaland (f. 1943) er pensjonert psykiater.

Litteratur

1. Noreng H, Knudsen T, Sommerfelt A. Norsk riksmålsordbok. 2. utg. Bd. 4. Oslo: Kunnskapsforlaget, 1983: 1960-2.

2. Gundersen D, Engh J, Fjeld RV. Håndbok i norsk. Skriveregler, grammatikk og språklige råd fra A til A. Bokmål. Oslo: Kunnskapsforlaget, 1995: 290. 